$$
\text { Veres Pál-Golovics fózsef }
$$

\title{
Tehermegosztás és pénzáramlások a felsőoktatásban: ki fizeti végül a révészt?
}

\section{Cost Sharing and Money Flows in Higher Education: Eventually, Who Pays the Ferryman?}

\section{Összefoglalás}

A tanulmány a felsőoktatás rendszerszintű finanszírozását elemzi a költség-haszon és a humántőke elmélet alapján. Arra a kérdésre keressük a választ, hogy hosszú távon, a képzési időn túli idődimenzióban, mely stakeholderek és miként viselik ténylegesen a felsőoktatás költségeit. Amellett érvelünk, hogy a költségek tényleges, hosszú távú megosztása nagyban függ az adórendszertől, amelyen keresztül a szereplők közvetett módon, gyakran utólagosan járulhatnak hozzá a felsőoktatás költségeihez. A költségek hasznokkal történő szembeállításával értelmezhetővé válik a finanszírozás haszonelvű egyensúlya is, amelynek implikációjaként elméleti érvek fogalmazódhatnak meg az államilag finanszírozott felsőoktatás és a progreszszív jövedelemadóztatás, valamint az önköltséges felsőoktatás és lineáris jövedelemadóztatás konstrukció-párok mellett.

Journal of Economic Literature (JEL) kódok: I2 1, I22, I26, H52

Kulcsszavak: felsőoktatás, finanszírozás, költség-haszon elmélet, humántőke elmélet

Dr. Veres PÁl PhD, nyugalmazott egyetemi docens, Budapesti Corvinus Egyetem (pal.veres@uni-corvinus.hu), Dr. Golovics József PhD, egyetemi adjunktus, Budapesti Corvinus Egyetem (jozsef.golovics@uni-corvinus.hu). 
Veres Pál - Golovics József: Tehermegosztás és pénzáramlások a felsöoktatásban: ki fizeti végül ...

\section{Summary}

This paper analyses the system-level funding of higher education (HE) based on the costbenefit approach and the human capital theory. We investigate that in the long run, taking into account the time dimension beyond the training period, which stakeholders actually bear the costs of HE. We claim that the actual, long-term costs sharing depends to a large extent on the tax system through which actors can contribute indirectly and often posteriorly to the funding of HE. Contrasting costs with benefits also makes it possible to interpret the utilitarian balance of funding, which implies that state-funded HE matches progressive income taxation, while private-funded HE fits well in countries that apply linear income taxation.

Journal of Economic Literature (JEL) codes: I2 1, I22, I26, H52

Keywords: higher education, funding of higher education, cost-benefit approach, human capital theory

\section{BeVEZETÉS}

Az elmúlt évtizedek a felsőoktatási rendszerek finanszírozásában jelentős eltolódást mutatnak az állam (a közfinanszírozás) és az egyéb szereplők (stakeholderek), különösen a családok (háztartások) részvételi arányait illetően. Elég, ha Magyarországon a költségtéritéses, illetve önköltséges képzés bevezetésére és elterjedésére utalunk, ami a 2004-2006-os csúcspontján a teljes hallgatói létszám nagyjából felét jelentette. A folyamat szoros összefüggésben állt a felsőoktatás abszolút és relatív tömegesedésével, és az abszolút tömegesedés végével sem zárult le. A társadalom részéről ugyanis továbbra is folyamatos és erőteljes igény jelentkezik a felsőoktatás iránt, ami a közfinanszírozás számára jelentett és jelent nagy kihívást. Mindez indokolttá teszi a felsőoktatási rendszer finanszírozási kérdéseinek, a stakeholderek közötti pénzmozgásoknak az alaposabb vizsgálatát, hogy pontosabb képet nyerjünk arról, hogy az egyes szereplők milyen arányban, milyen elvi, elméleti alapon és módon vesznek részt a finanszírozásban.

A finanszírozás elméleti és empirikus oldalról egyaránt sokoldalúan tárgyalt téma a felsőoktatás-kutatásban mind a nemzetközi (Barr, 2004; Vossensteyn, 2004), mind a hazai szakirodalmon belül (Kováts, 2006; Temesi, 2012). Ezek tárgyalásakor a magán- és a közfinanszírozásról egyaránt szó esik. Különös figyelmet érdemel ugyanakkor a két forma, illetve forrás közötti mélyebb kapcsolat tárgyalása, és ezáltal annak megértése, hogy a különböző pénzáramlások után hogyan alakul az oktatási tevékenység tényleges „végső” finanszírozása. Ebben pedig álláspontunk szerint az adórendszernek is fontos szerepe van. Erre világítottak rá Creedy \& Francois (1992), illetve Schindler (2011) munkái is, akik jóléti szempontból vizsgálták az adók és a tandíjak kombinációjának az oktatásra gyakorolt hatását. Utóbbira hivatkozva a progresszív személyi jövedelemadót Veres (2012) is az utólagos hallgatói hozzájárulások (magánfinanszírozás) egyfajta sajátos megnyilvánulásaként aposztrofálta. A költségmegosztás tárgyalásakor Semjén (2013) is érdemben foglalkozik a különböző tandíjkonstrukciók, bele- 
értve az utólagos költség-hozzájárulási rendszerek kérdésével, és az adózás ebben betöltött szerepével. Empirikus oldalról ugyancsak ezzel hozható összefüggésbe Németh (2012) megállapítása, amely szerint a hazai jövedelem-adózás progresszívről lineárisra történő átalakítása révén csökkentek a felsőoktatás társadalmi megtérülési rátái.

Tanulmányunkban a felsőoktatás stakeholderei közötti pénzáramlásokra kívánunk fókuszálni, szembe állítva azokat az érintettek felsőoktatásból származó hasznaival. Álláspontunk szerint így teljesebb kép nyerhető, nem csak a stakeholderek közötti tehermegosztásról, hanem annak különböző időszakonkénti alakulásáról is. Megközelítésünk lényeges eleme, hogy a költségek és hasznok kapcsolatát a képzési időn túlmutató idődimenzióban, hosszú távú összefüggésként értelmezzük. Ezzel azt kívánjuk hangsúlyozni, hogy a tényleges költségviselést, illetve költségviselőket csak hosszú távon lehet reálisan értelmezni, jóllehet, a rendszer működését folyamatosan finanszírozni kell, és ebben az összefüggésben értelmezhetők a „,rövidtávú finanszírozók” is. Mindazonáltal állításunk az, hogy a teljes pénzáramlást hosszú távon vizsgálva a stakeholderek költségviselése másként alakul, mint azt ma a jellemzően rövid távú szemlélet alapján készült statisztikák mutatják (OECD, 2020). Minél inkább progresszív ugyanis a személyi jövedelemadó rendszer, és minél magasabb a fogyasztást terhelő forgalmi adó, annál inkább - a végzést követően, az adórendszeren keresztül, indirekt módon, a diplomás bérprémium és az ebből származó fogyasztás adóterhelése révén - utólag jelentkezik a felsőfokú végzettségűek magasabb hozzájárulása a költségekhez. A munkaadók tekintetében pedig, mivel a magasabb végzettség hozzáadott érték-többletet eredményez - ami a diplomások bérprémiumában és a magasabb nyereségben jelentkezik -, a bérprémium és a nyereségadó egy része fogható fel utólagos képzési hozzájárulásként.

Mindezek tükrében tanulmányunk négy további szerkezeti egységre tagolódik. Először a gondolkodási keretünk alapját adó rendszerszemléletű megközelítést mutatjuk be, amelynek segítségével a felsőoktatás finanszírozását a gazdaság más alrendszereivel összekapcsolva - az alrendszerek közötti tranzakciókat is figyelembe véve - tárgyaljuk. Ezután kerül sor a felsőoktatás fő stakeholdereinek beazonosítására és a közöttük végbemenő - a felsőoktatásból származó hasznaikkal szembeállítható - pénzáramlások bemutatására. Itt a vonatkozó elméleti összefüggések, illetve a költség-haszon elv tükrében kísérletet teszünk a felsőoktatási rendszer finanszírozását illető tehermegosztás egy teljesebb körű leírására. Ennek nyomán külön fejezetben foglalkozunk az adórendszerek és a tehermegosztás közötti összefüggések tárgyalásával. Munkánkat végül a konklúziók összegzésével zárjuk.

\section{RendsZERSZEMLÉlET ÉS STAKEHOLDEREK}

Az általunk alkalmazott rendszerszemlélet alapvetése, hogy - mint azt az 1. ábra szemlélteti - a felsőoktatást az oktatási rendszer egyik alszektorának tekintjük, amely a többi alszektorral (közoktatás, szakképzés, felnőttképzés) is sajátos interakciókban áll. Az ezek együtteseként értelmezett oktatási rendszer ugyanakkor szintén egyike a társadalom különböző alrendszereinek. Utóbbiakkal rendre különböző kölcsönhatásban állhat, illetve interakciókat (tranzakciók és verseny) bonyolíthat le: az oktatás biztosítja például a gazdaság számára a képzett munkaerőt, akik jövedelmük és fogyasztásuk után adóznak. A közpénzügyi alrendszer - többek 
Veres Pál-Golovics József: Tehermegosztás és pénzáramlások a felsőoktatásban: ki fizeti végül ...

között a makrogazdasági realitások vagy éppen a politikai preferenciák figyelembevételével - ezen bevételek egy részét juttathatja vissza finanszírozásként az oktatási rendszer, illetve annak valamely alszektora számára. Jelen tanulmányban többek között ez utóbbi folyamat mechanizmusát és jelentőségét is szeretnénk részletezni. ${ }^{1}$

1. ábra: Az oktatás rendszerszemléletben

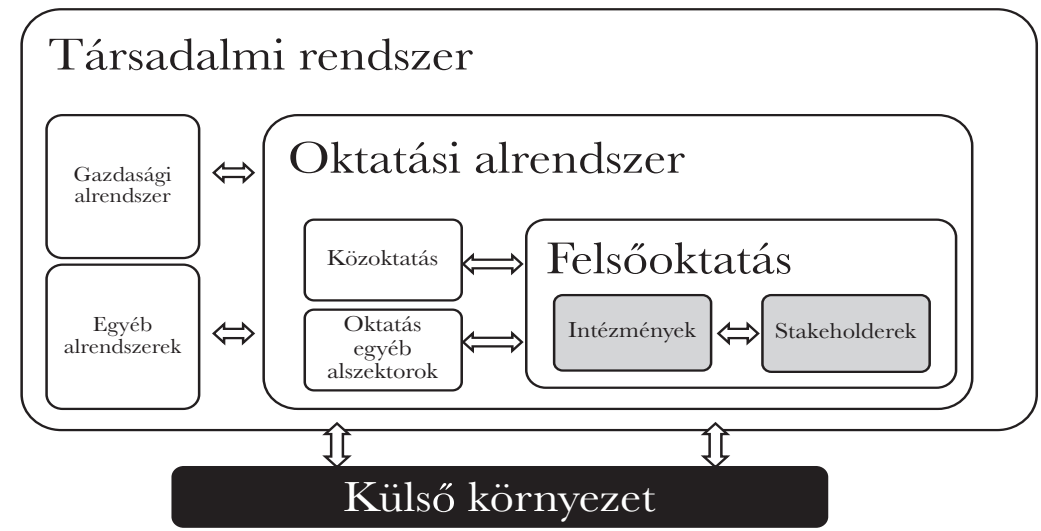

Forrás: saját szerkesztés

Az egyes alrendszerekben végbemenő és az alrendszerek közötti interakciók működéséről a North-féle (2010) institucionalista logikában gondolkodunk, ahol a szereplők közötti interakcióknak a vonatkozó szabályok adnak keretet, illetve strukturálják azokat. E tekintetben a felsőoktatási alrendszer és az ahhoz kapcsolódó pénzáramlások kapcsán a figyelmünket három ,elemre” kell fordítanunk:

- a felsőoktatás stakeholdereire,

- a közöttük lezajló interakciókra, valamint

- az ezen interakciók tekintetében releváns, az interakciókat is meghatározó formális és informális intézményekre.

A pénzmozgások bemutatására, illetve az érintett stakeholderek beazonosítására a következő fejezetben kerül sor.

Az alrendszerek, illetve a stakeholderek közötti interakciók fontos dimenziója az idő, ami a költség-haszon megközelítésben a költségek és hasznok időben történő eltávolodásában jelenik meg. Ahhoz, hogy a költségek és hasznok egyensúlyát minél jobb megközelítéssel azonosíthassuk, az alrendszerek és a stakeholderek közötti kapcsolatokat releváns időtávon kell megvizsgálnunk. Az alrendszerek, illetve stakeholderek közötti egyensúlyt a költség-haszon arányok kiegyenlítődése jelentené. Figyelembe kell ugyanakkor vennünk, hogy az általunk vizsgált felsőoktatási (al)rendszer különböző országokban különböző mértékben működik piaci alapon (a magyar rendszer például sajátos duális finanszírozású rendszer). A stakeholderek között kiemelkedő szerepe van a közjót szolgálni hivatott államnak, amely politikai szervezet és intézményrendszer is, politikai preferenciákkal. Ennek is betudható, hogy különböző országokban különböző mértékben, de eltérnek a költség-haszon egyensúlyi állapottól. 
Tanulmányunkban tárgyaljuk, illetve értelmezzük ezt az egyensúlyt, valamint egyensúly felé mozgást hosszú távon. Ehhez egy olyan keretet alkotunk, amely a felsőoktatásból származó hasznokat a különböző alrendszerek stakeholderei szintjén szembe állítja a finanszírozásként (költségviselésként) értelmezhető pénzáramlásokkal. A hasznok és pénzáramlások mögött az egyes országokra jellemző és a folyamat szempontjából releváns intézményrendszer áll, olyan elemekkel, mint például: tandíj, költségtérítés, állami támogatás vagy ösztöndíj, diákhitel rendszer, adórendszer. A fentebb kiemelt dinamikus egyensúlyi megközelítés mellett tanulmányunk másik fókusza az adórendszer szerepe a költség-haszon (finanszírozás-haszon) egyensúly létrejöttében. Azt nem állítjuk, hogy az egyensúly hosszabb távon mindig és minden országban létrejön. Azt ugyanakkor igen, hogy az általunk alkalmazott hosszabb távú szemlélet az egyensúlyhoz közelebbi állapotot ír le, mint a rövid távú szemlélettel készült statisztikák. Utóbbiak ugyanis a közvetlen forrásuk (teherviselő) alapján különböztetik meg a magán és közösségi finanszírozást (költségviselést). Lényegében azt mutatják meg, hogy a felsőoktatási intézmények költségvetésében a kiadásokat milyen - közvetlenül kitől származó - bevételekből fedezik. Nem vizsgálják ugyanakkor például a diplomaszerzés utáni, különböző intézményi formákban történő, többnyire indirekt hozzájárulásokat. Az állam, illetve az államháztartás, az adó- és költségvetési rendszer bekapcsolása tehát azért fontos, mert „közvetítő közegként” szolgálnak a stakeholderek közötti pénzáramlásokkor, az elemzésben pedig rajtuk keresztül követhető a tényleges, illetve végleges költségviselés.

\section{TEHERMEGOSZTÁS A PÉNZÁRAMLÁSOK TÜKRÉBEN}

Az oktatás pénzáramlásban érintett stakeholderei között a következőket azonosíthatjuk: a munkaadókat, a felsőoktatásban az életük valamely szakaszában részt vevő (a továbbiakban: „hallgató”) és a részt nem vevő (a továbbiakban: „nem-hallgató”) állampolgárokat (megkülönböztetve ezáltal a felsőfokú végzettséggel rendelkezőket és nem rendelkezőket), az egyetemeket és főiskolákat, illetve az államot. Ezen stakeholderek ugyanis azok, akik az oktatási szolgáltatásnak valamely „oldalán” jelen lehetnek: akár a hasznok élvezőjeként, akár a költségek viselőjeként. A nevesített stakeholdereket, a számukra jelentkező hasznokat (ez utóbbiakat rendre a vonatkozó stakeholderrel azonos „mezőben”) és a közöttük zajló pénzmozgásokat a 2. ábra szemlélteti.

\section{Pénzáramlás és haszon a felsöoktatási intézmény és a hallgató viszonyában}

A pénzáramlások elemzésekor a kiindulópontot az oktatási szolgáltatás átadása jelenti, amely tranzakció a hallgató és az egyetem, vagy főiskola² között zajlik le. A hallgató haszna ebből - a humántőke elmélet alapján (Becker, 1962) - a tudás, a saját humántőkéjének gyarapodása, ami gazdasági szempontból elsősorban a magasabb termelékenységében (hozzáadott értékben), és az ebből származó munkaerőpiaci előnyökben, diplomás bérprémiumban jelentkezik. 


\section{2. ábra: Pénzáramlások a felsőoktatásban}

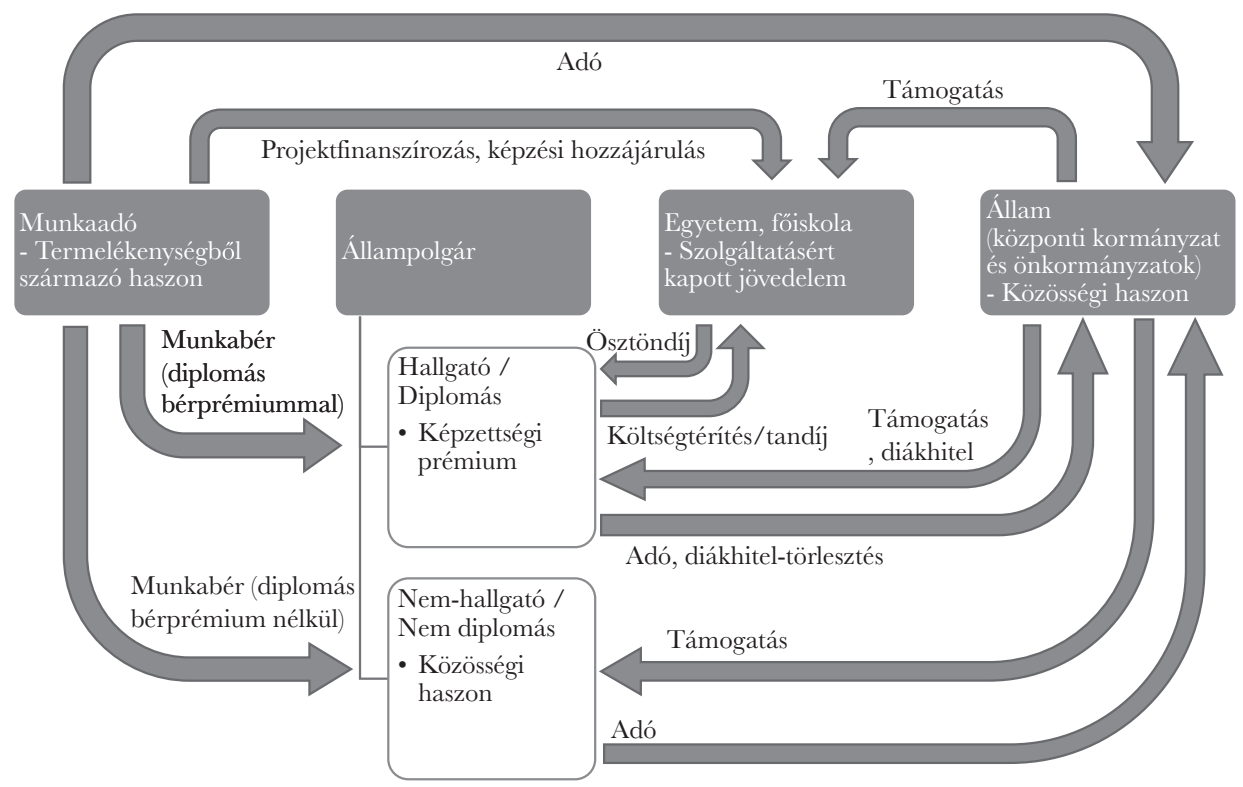

Forrás: saját szerkesztés

A felsőfokú végzettség további egyéni, pénzbeli és nem pénzbeli hasznairól - például magasabb megtakarítási ráták, jobb egészségügyi körülmények stb. - Vossensteyn (2004) ad áttekintést. Egy átlagos piaci tranzakció esetén az ilyen hasznos szolgáltatásokért többnyire a fogyasztó - jelen esetben a hallgató - fizetne, tehát közvetlenül ő állná a költségeket. Természetesen erre a felsőoktatásban is van példa, amikor költségtérítéses képzés esetén a hallgató a szolgáltatásnyújtással egyidőben ${ }^{3}$ tandíjat fizet az egyetem számára. Hangsúlyozandó ugyanakkor, hogy gyakran ebben a finanszírozási struktúrában sem az igénybe vevő viseli ténylegesen a terheket: tekintve, hogy a hallgatók jelentős része a középiskola elvégzését követően, önálló kereset és anyagi egzisztencia nélkül kezdi meg felsőfokú tanulmányait. Így az „önköltséget” gyakran nem ők maguk, hanem a családjuk állja. Ez utóbbi tény adott esetben a későbbi, családdal szembeni „elszámolás” kérdését is felvetheti. ${ }^{4}$ Azon hallgatók esetén pedig, ahol az önköltség fedezése a család bevonásával sem valósítható meg, további alternatívát jelenthetnek a különböző - Magyarországon is élő - diákhitel konstrukciók. Ezek esetében az utólagos elszámolás kérdése nyilvánvaló: a diákhitel törlesztése a képzési időt követően, a magasabb termelékenységből származó jövedelemből történhet meg. Így ezt a mechanizmust egyfajta közvetett-utólagos finanszírozásnak is tekinthetjük, amelyben a költségek jelentős részét továbbra is a hallgató viseli. ${ }^{5}$

A képzés közvetlen - a képzési idő alatt történő - hallgatói (családi) finanszírozása természetesen a méltányosság és az esélyegyenlőség szempontjából lehet kifogásolható. A diákhitel egy lehetséges intézményi megoldás e kihívás kezelésére. Ugyanakkor az anyagi szempontból hátrányos helyzetű családok hitelfelvételi hajlandósága alacsonyabb lehet (országonként el- 
térő mértékben, akár kulturális okokra visszavezethetően), továbbá a hallgató eladósodásához, negatív vagyon képzéséhez vezethet, ami újratermelheti a hátrányos helyzetet az önálló élet kezdetén. Természetesen ez a negatív vagyon elméletileg a diplomás bérprémium révén pozitív szaldójúvá változtatható, azonban ehhez több külső (például makrogazdasági, munkaerő-piaci helyzet) és belső feltétel (megfelelő szakmaválasztás, megfelelő elkötelezettség és teljesítmény a felsőoktatásban és a munkaerőpiacon stb.) is szükséges. Mindez pedig élesen mutat rá az oktatás kockázattal járó (humántőke-) beruházás-jellegére, illetve az egyéni felelősség fontosságára is.

\section{Az állam szerepe, a felsöoktatás közfinanszírozása}

A fent tárgyaltak és a globális gyakorlat szerint a felsőoktatási szolgáltatásért nem kizárólag a közvetlen igénybe vevők, a hallgatók, illetve családjuk fizetnek. Ez elméleti szempontból a költség-haszon elv alapján indokolható. A társadalom képviseletében eljáró államnak a felsőoktatás - közjószág-jellegű és pozitív extern hatásokkal bíró természete (Veres \& Golovics, 2012), azaz - közösségi hasznai miatt állhat érdekében a költségek átvállalása. Ide sorolhatjuk például a magasabb nemzeti termelékenységet, a nagyobb társadalmi mobilitást vagy épp az alacsonyabb bűnözési rátákat (a közösségi hasznokról bővebben lásd Vossensteyn, 2004). ${ }^{6}$ Ebben az esetben a felsőoktatásban való részvétel a képzési idő alatt a hallgatók számára teljesen vagy részben ingyenes, illetve tandíjmentes, a terhek viselése pedig az államra, és rajta keresztül a társadalom többi részére, tehát azon tagjaira is hárul, akik nem vették igénybe a felsőoktatási szolgáltatást. Ekkor a költség-haszon elv érvényesülését a közösségi hasznok biztosíthatják. Annak vizsgálata, hogy utóbbiak milyen arányban vannak a felvállalt költségekkel, és ezek relációja tükrében a közösség számára mennyire tekinthető racionálisnak ez a fajta humántőke-beruházás, túlmutat jelen tanulmány keretein. ${ }^{7} \mathrm{Az}$ mindenesetre Németh (2012) gyűjtése alapján elmondható, hogy a felsőoktatás társadalmi megtérülési rátái rendre pozitívak az OECD-országokban, ám az is látható, hogy ezek a legtöbb esetben alacsonyabbak az egyénieknél. Ez a felvállalt költségeken túl azzal állhat összefüggésben, hogy a felsőfokú tanulmányok esetén általában a képzés egyéni hasznai is lényegesen nagyobbak a közösségi hasznoknál (Vossensteyn, 2004).

A költségmegosztás tanulmányunk által kifejtett, az idődimenziót és az adórendszert is figyelembe venni javasolt megközelítésének fontosságát a 3. ábra is megmutatja. Az ábra a hagyományos, rövid távú, a képzési időre szorítkozó és közvetlen finanszírozási megközelítést tükrözi. Mint látható, az egyes országok között jelentős különbségek vannak a közösségi- és a magánfinanszírozás arányait tekintve, ami ugyanakkor a költség-haszon elv alapján nehezen lenne magyarázható.

Az ábra alapján, hipotézisünk az lehet, hogy a nagyon magas közfinanszírozású országokban valamilyen utólagos hozzájárulást, például az adórendszeren keresztül történő indirekt magánfinanszírozást kellene találnunk. A nagyon magas magánfinanszírozású országokban viszont az adórendszer tekintetében tételezhetünk alacsonyabb marginális kulcsokat. ${ }^{8}$ 
3. ábra: Közösségi- és magánfinanszírozás aránya a felsőoktatási intézményekben (2017)

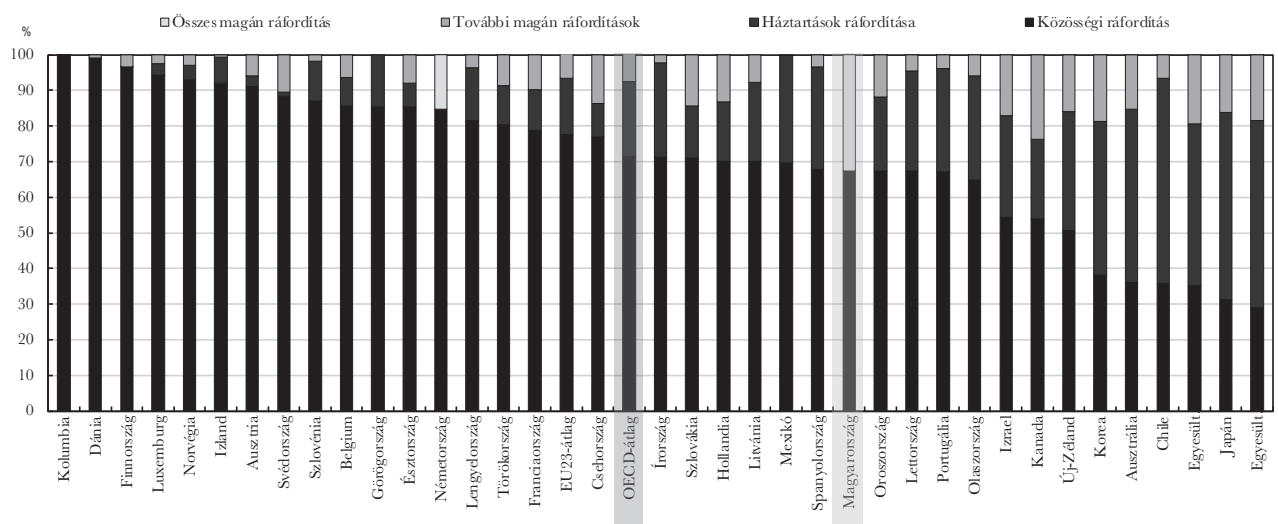

Forrás: OECD (2020) nyomán. https://doi.org/10.1787/f456fd53-en

A magyar felsőoktatásban a hallgatók háromféle - állami ösztöndíjas, állami részösztöndíjas és az önköltséges - képzésben vehetnek részt. A finanszírozási státusok közötti, teljesítmény alapú átsorolásról a nemzeti felsőoktatásról szóló törvény rendelkezik. Ez mindenképpen bonyolítja a költség-haszon alapú finanszírozás érvényesülését és egyben nehezíti az értelmezését is. Amennyiben ugyanis következetesen érvényesíteni akarjuk, hogy a „haszonélvező” a költségekből is vállaljon, akkor az állami ösztöndíjas képzésben részt vevők esetén erre a képzési idő után, utólagos direkt (képzési hozzájárulásként) vagy indirekt módon (az adórendszeren keresztül) van lehetőség. Az önköltséges képzésben részt vevők magas egyéni hozzájárulásának „kompenzálására”, kiegyensúlyozására jelenleg nincs megoldás. A kétféle státusz közötti átsorolást dinamikus, azaz ösztönző-motiváló elemnek tekintjük, de jellegéből fakadóan nem a költség-haszon alapú finanszírozás egyensúlyi helyzetének elérését segíti elő.

Ha az államról, illetve a közfinanszírozásról beszélünk, akkor nem kerülhető meg az önkormányzatok szerepe sem. Utóbbiak részvétele a finanszírozásban szorosan összefügg a „,belső migráció” problémájával és az egyik legkonfliktusosabb dimenziója a költség-haszon elvű finanszírozásnak. Ha az iskolai rendszer teljes vertikumát nézzük, akkor egy adott önkormányzat területéről a felsőoktatásba kerülő és ott diplomát szerző állampolgár a család és az állam részéről jelentős humántőke beruházásban részesül. A központi állam esetében a konfliktust a nemzetközi migráció okozza (Golovics, 2015). A probléma a belső migráció révén az önkormányzatok szintjén hasonló módon jelentkezik. Az önkormányzat által képviselt közösség érdeke ugyanis az, hogy a közösségből a felsőoktatásba kerülők minél nagyobb hányada visszatérjen alkalmazottként vagy vállalkozóként, és az adott önkormányzat közösségének javára is kamatoztassák humántőkéjüket. S bár hazánkban a belső migráció mértéke kirívóan alacsony, az elmondható, hogy a vándorlásra leginkább a fiatal, jól képzett polgárok hajlamosak (Sebők, 2016). Ez a tény pedig hozzájárul az országon belüli egyenlőtlen fejlődés további erősitéséhez. Reális célkitűzés lehetne ezért rövid-közép távon az ebből fakadó 
egyensúlytalanság csökkentése. Ehhez az önkormányzatok aktívabb szerepet játszhatnának olyan finanszírozási konstrukciókkal, amelyek érdekeltté teszik diplomásaik visszavándorlását. E tekintetben ki kell emelnünk a kormány és a helyi önkormányzatok által működtetett Bursa Hungarica Felsőoktatási Önkormányzati Ösztöndíjat, amely kifejezetten az esélyegyenlőség javítását célozza. Megemlítendő továbbá a „Magyar falu program”, amely felfogásunk szerint értelmezhető a központi állam méltányos vidékfejlesztési hozzájárulásaként, az országon belüli agyelszívás kompenzálásáért, mértékének csökkentéséért vagy akár megfordításáért. ${ }^{9}$

\section{A felsöoktatás közfinanszírozása mint állampolgári teherviselés}

Tévedés lenne ugyanakkor itt megállni a teherviselés vizsgálatában, s a közfinanszírozás forrásaként egyszerűen a „közpénzt” megjelölni. Az államnak ugyanis eredendően nincs „saját” pénze, s bár arra már az előző bekezdésben is utaltunk, hogy ebben a konstrukcióban a tényleges terhet a társadalom viseli, indokoltnak látjuk ennek mélyebbre nyúló tárgyalását is. Amint ugyanis a jövedelemáramlásokat szemléltető 2. ábra is mutatta, az államhoz befolyó pénzek több stakeholder irányából, adó formájában érkeznek. ${ }^{10}$

Az adózás egyik legfőbb alanya maga az állampolgár, aki mind munkája, mind pedig fogyasztása után adót fizet a közpénzügyi rendszerbe. Köztük egyaránt jelen vannak olyanok, akik életük bizonyos szakaszában részt vettek a felsőoktatásban és olyanok is, akik nem. Világos azonban, hogy a közös teherviselés révén valamilyen mértékben utóbbiak is részt vesznek a felsőoktatás költségeinek fedezésében. Erre - a költség-haszon elv alapján - az érv továbbra is a közösségi hasznokból való részesedés lehet. Mindazonáltal a 2. ábrán látható összefüggések azt is világossá teszik, hogy a képzésben részt vevő polgárok még az állami finanszírozású felsőoktatási rendszerekben is részt vállalnak a teherviselésben. Ez a részvállalás azonban - hasonlóan a diákhitel-rendszerhez - közvetett és utólagos: itt a képzés tandíjmentessé tételével az állam kvázi-hitelt nyújt a hallgatóknak, akik ezt a végzést követően, a magasabb képzettségnek köszönhető magasabb termelékenység révén elérhető magasabb fizetésükből adó formájában térítik meg. Mindez pedig arra mutat rá élesen, hogy a felsőoktatás tényleges tehermegosztásában az adórendszer kulcsfontosságú szerepet játszik, hiszen az adórendszer milyensége - a különböző adótípusok egymáshoz viszonyított aránya, az egy- vagy többkulcs használata, illetve a kulcsok nagysága - alapjaiban határozza meg, hogy a különböző stakeholderek milyen arányban viselik a felsőoktatási képzések terheit (ami természetesen szembeállítható az abból származó hasznaik mértékével). Ennek részleteit a tanulmány későbbi fejezetében tárgyaljuk.

\section{A munkaadók részvétele a felsőoktatás finanszírozásában}

További fontos stakeholderei a felsőoktatásnak a munkaadók: ők azok, akik foglalkoztatják a felsőoktatásból kikerülő, értékesebb humántőkéjű és magasabb termelékenységű munkavállalókat, s élvezik az ebből származó hasznokat: a magasabb vállalati termelékenységet, innovativitást és az ennek nyomán keletkező profitot. Utóbbira hivatkozva gyakran felmerül a közbeszédben, hogy a hasznok ellentételezéseként a munkáltatóknak (vállalatoknak) is 
Veres Pál - Golovics József: Tehermegosztás és pénzáramlások a felsöoktatásban: ki fizeti végül ...

szerepet kellene vállalniuk a költségek viselésében. Ez az igény-megfogalmazás azonban azt a téves gondolatot is magában foglalja, hogy ez jelenleg nincs így. Amint ugyanis a 2. ábra szemléltette, a munkaadók mind közvetve, mind közvetlenül részt vállalnak a felsőoktatási képzések költségeinek viseléséből. Egyrészt elmondható, hogy egyedi megállapodások alapján közvetlen kapcsolatban állhatnak egyetemekkel, s például ösztöndíjprogramokat, kutatási projekteket finanszírozhatnak utóbbiak számára. ${ }^{11}$ Másrészt adóznak, amelynek révén ugyancsak pénzt juttatnak az állami költségvetésbe, s mivel a felsőfokú képzésből származó humántőkét „használó” vállalatok jellemzőbben profitábilisabbak, a befizetett adó mértéke együtt mozoghat a foglalkoztatott diplomások számával. Harmadrészt, s ami témánk szempontjából a legfontosabb, a munkaadók közvetlenül a diplomás foglalkoztatottaknak fizetnek azok képzettségének és értékesebb humán tőkéjének a „használatáért”. A nekik fizetett bérek pedig - mint azt a 4. ábra is mutatja - jellemzően jóval nagyobbak, mint az alacsonyabb végzettségűek fizetései. S tekintve, hogy a szóban forgó munkavállalók adóznak a munkajövedelmükből (vagy akár diákhitelt törlesztenek), elmondható, hogy a munkaadók ezen a diplomás bérprémiumon keresztül veszik ki részüket leginkább - szintén utólag és közvetve - a felsőoktatás költségeinek viseléséből. ${ }^{12}$

4. ábra: A diplomás bérprémium mértéke a középfokú végzettségúekhez viszonyítva az OECD-országokban (2018)

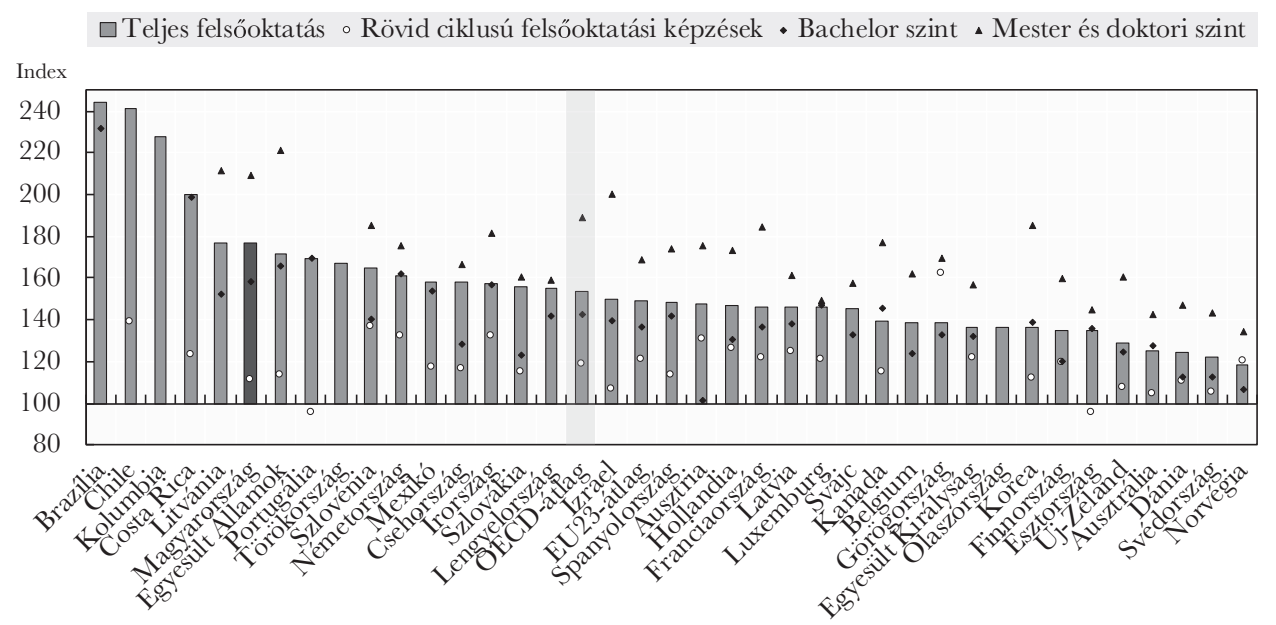

Forrás: OECD (2020) nyomán. https://doi.org/10.1787/888934162470.

Megjegyzés: Amint az ábrán látható, a diplomás bérprémium mértéke Magyarországon kimagasló, meghaladva mind az OECD-, mind az előbbi szervezetben is tag EU-tagállamok átlagát. 2018-ban egy alapszintű diplomával több, mint másfélszeres, míg mesterszintű diplomával több, mint kétszeres fizetésre lehetett átlagosan számítani hazánkban. 


\section{Polgári Szemle $\cdot$ 17. évfolyam 4-6. szám}

A finanszírozás dinamikus elemei: ösztöndíjak, támogatások

A fentieken túl néhány további pénzáramlás is kiemelhető a stakeholderek között, amely a 2. ábrán is szerepelt. Ezek egyike az ösztöndíj, amely az egyetemtől érkezik a hallgatóhoz. ${ }^{13}$ Ez a juttatás alapulhat tanulmányi teljesítményen vagy szociális helyzeten, de mindenképpen hangsúlyozandó, hogy ezáltal a hallgató a humántőkéjének gyarapodása mellett újabb haszonnal járó „elemet” is kap az egyetemtől. Ennek forrása pedig az előzőekben tárgyaltakhoz hasonlóan terhelheti a társadalom különböző csoportjait. A tanulmányi ösztöndíj tanulmányunk költség-haszon logikájában felfogható egy olyan dinamikus ösztönzőként, amelynek célja a kompetenciaszint emelésével a későbbi foglalkoztatás során az egyéni- és a közhaszon növelése. Ábránk alapján az állami ösztöndíj mint közköltség a közösségi hasznokon keresztül térül meg, a magánhaszon pedig az adórendszeren keresztül ellentételeződhet a közösség számára. A szociális ösztöndíj tekintetében is a dinamikus hatást emeljük ki, ami az esélyegyenlőség elősegítésén, a tehetségesek szélesebb körének feltárásán keresztül a már bemutatott mechanizmusban vezet a közhaszon növekedéséhez, a magán, illetve munkaadói hasznok megadóztatásán keresztül is.

Ezen felül említést érdemelhetnek azon támogatások is, amelyek az állam irányából érkeznek az állampolgárok felé (e kategóriába akár a legkülönbözőbb közszolgáltatásokból való részesedést is besorolhatnánk, de a terjedelmi korátok miatt itt elsősorban a monetizált támogatások tárgyalására szorítkozunk). Ezek jelentős része - noha ellenpéldák is bőven akadnak - szociális alapú, s többnyire a kedvezőtlenebb anyagi helyzetben lévő polgárokat célozza. Így, figyelembe véve, hogy a magasabb képzettségűek általában magasabb keresetekkel rendelkeznek (mint azt a 4. ábra is mutatta), s a kormányzattól való kisebb függést is a felsőoktatás közösségi hasznai között szokás említeni (Vossensteyn, 2004), valószínűsíthető, hogy a diplomások ezen támogatásokból kisebb arányban részesednek. S jóllehet, itt többszörös áttéten érkező pénzmozgásokról, illetve jelentős általánosítással beazonosított társadalmi csoportokról beszélünk, elvi szinten megfogalmazható, hogy ezen támogatások egyfajta kompenzációként, ,kárpótlásként” értelmezhetők a felsőoktatás egyéni hasznaiból nem részesülő állampolgárok számára (amelynek fedezetét részben a diplomások magasabb kereseteiből származó magasabb adóbevételek biztosíthatják). Mindazonáltal ezen relációkban a terhek és a hasznok aránya országonként és időpillanatonként eltérő, s függ többek között az adórendszertől, a szociális juttatások rendszerétől, valamint a felsőoktatás finanszírozásának a metódusától, így minden esetben külön elemzés tárgyát képezheti.

\section{ADÓRENDSZER ÉS FELSŐOKTATÁS-FINANSZÍROZÁS}

Amint az az előző fejezetből világossá vált, az adórendszer kulcsszerepet játszik abban, hogy a felsőoktatás költségei miként oszlanak meg az egyes stakeholderek között. Ennek megfelelően a következőkben a különböző adózási megoldások tehermegosztásra gyakorolt hatásait tekintjük át, összekötve ezeket a felsőoktatás-finanszírozás alapvető formáival.

Elsőként a munkát terhelő, személyi jövedelemadót érdemes tekinteni, amelynek rendszere alapvetően kétféle lehet: lineáris vagy progresszív ${ }^{14}$. Progresszív adózás esetén elmondható, hogy a diplomások, akik jellemzően magasabb jövedelemmel is rendelkeznek (lásd 4. 
ábra), ezen magasabb keresetük után magasabb adókulccsal is adóznak. Így azokhoz képest, akik nem vettek részt a felsőoktatásban, s így - a nagy átlagok szintjén legalábbis - alacsonyabb keresettel bírnak, az előbbiek mind számszerűleg, mind a jövedelmük arányában több jövedelemadót fizetnek. Ez pedig azt jelenti, hogy a közteherviselésből, ami a felsőoktatás költségeinek fedezetéül is szolgálhat, ceteris paribus nagyobb arányban veszik ki a részüket. Így a jövedelem progresszív adóztatása elméleti szempontból jól illeszkedik az „állami finanszírozású” („tandíjmentes”) felsőoktatáshoz: ezen konstrukciók mentén ugyanis az állam (s rajta keresztül a közösség) átvállalja a felsőoktatásban való részvétel költségeit a hallgatótól, aki később, a munkaerőpiacra lépve a magasabb jövedelme nyomán fizetett nagyobb adótömeg révén „téríti meg” utólag és közvetve a társadalom számára azt. Így az ingyenes felsőoktatást biztosító országokban a progresszív jövedelemadó alkalmazása nem csak a fizetőképességi, hanem a haszonelv (Musgrave \& Musgrave, 1993) alapján is méltányosnak tekinthető. Utóbbi szempontból kiemelve azt az aspektust, hogy az járul hozzá arányaiban is nagyobb mértékben a közös terhek viseléséhez, aki - itt kifejezetten a felsőoktatásra fókuszálva - a közszolgáltatásokból is nagyobb mértékben részesedik. ${ }^{15}$ Ezzel párhuzamosan az önköltséges felsőoktatást működtető országokban - az előbbi elvek mentén, továbbra is a felsőoktatási vonatkozást helyezve fókuszba - a lineáris jövedelemadóztatás mondható adekvátabbnak. E mögött az a normatív érv húzódhat meg, hogy ha az állam nem vállalt részt az egyén humántőke-beruházásából, annak ,gyümölcséből”, a diplomás bérprémiumból se vonjon el többet adó formájában, mint a munkaerőpiac többi szereplőjétől. ${ }^{16}$

Hasonló szempontok alapján tekinthető át a fogyasztást terhelő adók kérdése is. Itt a kiindulópontot az jelenti, hogy a diplomások a magasabb jövedelmükből elviekben többet is fogyaszthatnak. Az általános közgazdasági megfontolások szerint azonban az emberek jelentős része a magasabb jövedelmet nem költi arányosan fogyasztásra. Így, ha az állam ingyenes felsőoktatást biztosít, és a korábban említett haszonelvet kívánná érvényre juttatni a fogyasztás adóztatásában, akkor annak termékcsoportonként eltérő forgalmiadó-kulcsok lehetnének az eredményei: jelesül magasabb adókulcsok a tehetősebbek által fogyasztott termékekre. Emellett azonban fontos szempontként emelhető ki az is, hogy a magasabb jövedelműek a fogyasztásra el nem költött pénzt megtakaríthatják, befektethetik, így - továbbra is a felsőoktatás finanszírozás szempontjára fókuszálva - a haszonelvű adózás alkalmazása kapcsán értelmezhető utólagos visszatérítés az előbbiek magasabb kulccsal történő adóztatása révén lenne megvalósítható. ${ }^{17}$ Magyarország esetében témánk szempontjából is releváns, hogy az alacsony egykulcsos személyi jövedelemadó mellett „szükségszerűen” - OECD viszonylatban is - magas a fogyasztás és különösen a magasabb jövedelműek által fogyasztott termékcsoportok adóterhelése.

\section{KONKLƯZIÓ}

Tanulmányunk a felsőoktatás-finanszírozás több fontos, részben további kutatást is igénylő aspektusára világított rá. Vizsgálatunk elméleti alapjául a felsőoktatás rendszerfinanszírozásának költség-haszon elméletét és a humántőke elméletet tekintettük, a rendszer és intézményi paradigma kontextusában. Ennek lényege, hogy valamennyi stakeholder hozzájárulásának 
összefüggésben kell lennie azokkal a hasznokkal, amelyek a felsőoktatásból, illetve annak révén nyerhetők. A költség-haszon elmélet motivációs elméletnek is tekinthető, hiszen ösztönöz a felsőoktatás mint szolgáltatás közvetlen (tanulás révén történő) és közvetett (például diplomások foglalkoztatása révén történő) igénybevételére, illetve a szolgáltatásért költségek vállalására. A költség-haszon, illetve humántőke elméletek a maguk nyers formájában azonban számos problémát felvetnek. Ezek közül a társadalmi érdek szempontjából kiemelten fontos a tehetségek feltárása és gondozása, ami egyes stakeholderek (elsősorban családok) esetében költségvetési korlátokba ütközhet, illetve ütközik is. Megállapítottuk továbbá, hogy a statisztikai adatok alapján a magán és közfinanszírozás arányait, illetve technikáit tekintve jelentős eltérések tapasztalhatók az egyes országok között. Az eltérések azonban olyan mértékűek, ami ellentmondani látszik a költség-haszon elmélet alkalmazásának. A finanszírozást hosszabb időtávon vizsgálva további összefüggésekre bukkantunk, illetve a tényleges finanszírozók tekintetében is fontos megállapításokat tettünk.

A statisztikák jelenleg az egyetemek költségvetésén, azok bevételi oldalán keresztül vizsgálják a stakeholderek hozzájárulását, amit mi közvetlen finanszírozásként (tandíj, önköltség térítés, állami támogatás stb.) értelmeztünk. Hosszabb távon vizsgálva azonban a stakeholderek közötti pénzáramlásokat, nem lehet megkerülni az adórendszer bekapcsolását, ami a személyi jövedelemadó, a forgalmi típusú adók és a vállalati nyereségadó figyelembevételét egyaránt jelenti. Mindez azért is fontos, mert a közjót képviselő állam a közfinanszírozáshoz az adórendszeren keresztül „szerzi a forrásokat”. Ezért nagy a jelentősége annak, hogyan adóztatja az állam a diplomásokat és a diplomásokat alkalmazó munkaadókat, akik a felsőoktatás nyilvánvaló haszonélvezői.

A költség-haszon elmélet alapján elvárásunk az, hogy amennyiben (ahol) a közvetlen finanszírozás átlag fölötti magán-hozzájárulási arányt mutat, ott ezt az „,aránytalanságot” az adórendszer korrigálhatja alacsonyabb átlagos, illetve kevésbé progresszív, esetleg egykulcsos személyi jövedelemadóval. Így az adórendszer a költségek fedezésére szolgáló pénzek egy részét nem vonja el a diplomásoktól. Az ilyen rendszerekben a tandíjak fedezésére szolgáló diákhitel természetes, dinamikus áthidaló elem. Ezzel szemben, ahol a közvetlen finanszírozásban az állami részvétel szembetűnően magas (tandíjmentesség, ,ingyenes” felsőoktatás), ott a magán hozzájárulás a személyi jövedelem adóztatásán (magasabb átlagos adókulcs, többkulcsos, progresszív rendszer, magas marginális adókulcs) érvényesülhet. A forgalmi típusú adók ugyancsak játszhatnak hasonló szerepet az utólagos magánfinanszírozásban, illetve kompenzációban, ám az adónem indirekt jellegénél fogva az érintettek mozgástere nagyobb a tényleges adóteher befolyásolásában. Ezen felül rávilágítottunk arra, hogy a munkaadók részvétele a felsőoktatás finanszírozásában közvetett, s elsősorban a diplomásoknak fizetett bérprémium, másodsorban az adózás révén valósul meg.

További kutatást igényel, hogy az adórendszer bekapcsolásával valósághoz közelibb képet alkossunk a felsőoktatás költségeinek stakeholderek közötti megosztásáról az egyes országokban, továbbá az egyes mechanizmusok mellékhatásairól, különös tekintettel a tehetségek minél szélesebb körű feltárására, bevonására és gondozására, ami alapvető közérdek. A magyar duális finanszírozású rendszer „láthatóan” nehezen kezelhetővé teszi a hasznokhoz közelítő költségmegosztást. A bérprémium hazai vonatkozásban magas, azonban a diplomás 
bérszínvonal nemzetközi vonatkozásban alacsony, ami indokolhatja az alacsony adókulcsot az alapvetően egykulcsos rendszerben. A nemzetközi összehasonlításban magas forgalmi adókulcs ugyanakkor már a magánhaszon részbeni elvonásaként is értelmezhető.

$$
\text { JEGYZETEK }
$$

1 Az oktatási rendszer természetesen nem csak az adott ország társadalmi alrendszerei közé van beágyazódva, hanem a nemzetközi, globalizált térbe is. Erről bővebben lásd: Golovics-Veres (2020).

2 A tanulmány további részében az oktatási szolgáltatást nyújtó szervezetekre az egyszerűség kedvéért csak egyetemként hivatkozunk. A „felsőoktatási intézmények” kifejezés ugyan alternatívaként szolgálhatna, amely az egyetemek mellett magába foglalja a főiskolákat is, mivel azonban az institucionalista szemlélet North (2010) nyomán élesen elkülöníti a szervezetek és az intézmények fogalmát, ezt a megnevezést zavarónak éreznénk, így eltekintünk tőle.

3 Bár a tandíj intézménye kapcsán általában a képzési idő alatt fizetendő formára szoktunk gondolni, a szakirodalom értekezik az utólagos vagy halasztott tandíjak, illetve hozzájárulások lehetőségéről is (lásd például Semjén, 2013), amely szintén egyfajta reflexióként értelmezhető az általunk tárgyalt, időben eltolódó költségmegosztás problematikájára.

4 Tanulmányunknak nem tárgya, de további kutatások tekintetében meg kell jegyeznünk, hogy a hallgatókat tanulmányaik idején terhelő díjfizetésekhez társított motivációs (ösztönzési) várakozások megalapozottságát erősen gyengítheti, hogy a tulajdonképpeni költségviselő nem maga a hallgató, hanem a családja. Így előbbi költségvetési korlátja a Kornai-féle (1980) értemben puhának tekinthető.

5 A terhek viselésében ugyanakkor bizonyos mértékben - a közösség képviseletében - az állam ebben az metódusban is szerepet vállalhat annak függvényében, hogy az állami diákhitel-konstrukció mennyivel bizonyul esetleg kedvezőbbnek a többi, pénzpiaci alternatívához képest.

${ }^{6}$ Bár jelen megközelítésünkben a költség-haszon elv, s ezzel összefüggésben a hatékonyság jelenti a kiindulópontot, tagadhatatlan, hogy az állami szerepvállalásnak más motivációi is lehetnek. Ezekről bővebben lásd Veres-Golovics (2012), részletesebben a méltányossági szempontról, illetve annak a költség-haszon elvvel való összeférhetőségéről pedig Veres (2012).

7 Ezen humántőke-beruházásnak egy speciális szempontját, az elvándorlás esetén történő megtérülés kérdését tárgyalja Golovics (2015).

$8 \quad$ Ezen hipotézisek tesztelése későbbi kutatás tárgya lehet.

9 A vidék, különösen pedig a falvak vonzerejének erősítéséről lásd még Veres (2018).

10 Az állami költségvetésbe befolyó pénzek, illetve a teljes közpénzügyi rendszer szerkezetének átfogó áttekintése természetesen meghaladná jelen tanulmány kereteit (ezekről bővebben lásd például Lentner, 2017). Ezért itt csak a felsőoktatási vonatkozású tényezőkre, illetve a felsőoktatás stakeholderei között történő jövedelemáramlásokra fókuszálunk.

${ }^{11}$ Az e csatornán érkező pénzmennyiség mértékének megítélése normatív szempontból természetesen vita tárgyát képezheti, de azt fontos látni, hogy ez a fajta finanszírozás mindig kétoldalú megállapodáson alapul, amelyben a profitmaximalizáló finanszírozó, azaz a vállalat számára a megtérülés jelenti a kulcskérdést.

12 Ezen a ponton kell megemlíteni, hogy a globalizáció a működő tőke globális mozgása kapcsán az eltérő fejlettségủ országokban a felsőoktatás költségeinek haszon alapú megosztásában erőteljes aránytalanságokat hozott létre. Az azonos termelékenység esetén érvényesített szignifikánsan eltérő bérszínvonal értelmezésünkben azt jelenti, hogy a működő tőkét mozgató vállalatok nem járulnak hozzá a hasznuk arányában a munkaerő származási országának felsőoktatási költségeihez.

13 Természetesen a hallgatók a 2. ábrán szereplő többi stakeholdertől is részesülhetnek ösztöndíjban. Ezek részletezésétől azonban terjedelmi okból kénytelenek vagyunk eltekinteni.

14 A harmadik típus, a regresszív adózás tárgyalásától a terjedelmi korlátok, valamint a relevanciájának hiányában eltekintünk. 


\section{Polgári Szemle $\cdot 17$ évfolyam 4-6. szám}

15 Külön említést érdemelhet azon eset, ahol a progresszív jövedelemadóztatás mellett a felsőoktatás finanszírozása duális rendszerben történik. Itt ugyanis az önköltséges képzésben részt vevők a diplomás bérprémiumuk magasabb kulccsal történő adóztatása révén kvázi „kétszer fizetnek” a képzésért. E konstrukcióban ezért a költség-haszon megközelítés alapján akár valamilyen adókedvezmény biztosítása is megfontolandó lehet az önköltségen diplomát szerzett polgárok számára.

16 Ebben a konstrukcióban, mint arra korábban is utaltunk már, a felsőfokú tanulmányok finanszírozása piaci, vagy kvázi-piaci úton biztosítható, hitel vagy diákhitel formájában. Fontos azonban látni, hogy az utólagos visszatérítés - az állami finanszírozás és progresszív adóztatás konstrukciójához hasonlóan - itt is megtörténik, azzal a különbséggel, hogy a diplomás bérprémiumból az állampolgár nem több adót, hanem (diák)hitel-törlesztést fizet.

${ }_{17}$ Az itt tárgyaltakon túl az adórendszer további, direktebb csatornákon is alkalmas lehet a haszonelv érvényesítésére a felsőoktatás költségeinek viselése tekintetében. Ilyen megoldás lehet a Vossensteyn (2004) által is említett diplomás adó (graduate tax) is, amelynek tárgyalása külön tanulmány tárgyát képezhetné. Az adóról áttekintést ad Dietsch (2006).

\section{Felhasznált irodalom}

Barr, Nicholas (2004): Higher Education Funding. Oxford Review of Economic Policy, Vol. 20, No. 2, 264-283.

Becker, Gary S. (1962): Investment in Human Capital: A Theoretical Analysis. Fournal of Political Economy, Vol. 70, No. 5, 9-49.

Creedy, John - Francois, Patrick (1992): Higher Education and Progressive Taxation: Equity, Efficiency and Majority Voting. Fournal of Economic Studies, Vol. 19, No. 4, 17-30.

Dietsch, Peter (2006): Financing higher education: the case for a graduate tax. The Ethics Forum, Vol. 1, No. 1, $88-102$. Golovics József (2015): A hallgatói szerződések közgazdaságtana. Sugo Szemle, Vol 2, No. 1, 104-111.

Golovics József - Veres Pál (2020): Felsőoktatás és globalizáció. Egy tranzakciósköltség-alapú megközelítés. Polgári Szemle, Vol. 16, No. 4-6, 186-199.

Kornai János (1980): A hiány Közgazdasági és Jogi Könyvkiadó, Budapest.

Kováts Gergely (2006): A felsőoktatási intézmények finanszírozási modelljei. Közgazdasági Szemle, Vol. 53, No. 10, 919-938.

Lentner Csaba (2017): Közpénzügyi menedzsment.Dialóg Campus Kiadó, Budapest.

Musgrave, Richard A. - Musgrave, Peggy B. (1993): Az egyenlő teherviselés (az adózási méltányosság) megközelítési módjai. Szociálpolitikai Értesitó, No. 1-2, 32-56.

Németh András Olivér (2012): Felsőoktatás-finanszírozás Kelet-Közép-Európában. In: Temesi József (szerk.): Felsőoktatás-finanszírozás. Nemzetközi tendenciák és a hazai helyzet. Aula Kiadó, Budapest, 67-102.

North, Douglass C. (2010). Intézmények, intézményi változás és gazdaság teljesítmény. Helikon Kiadó, Budapest.

OECD (2020): Education at a Glance 2020: OECD Indicators. OECD Publishing, Paris. https://doi.org/10.1787/69096873-en.

Schindler, Dirk (2011): Tuition Fees and the Dual Income Tax: The Optimality of the Nordic Income Tax System Reconsidered. German Economic Reviewe, Vol. 12, No. 1, 59-84.

Sebők Marianna (2016): Munkaeró-piaci mobilitás Magyarországon. Edge 2000 Kiadó, Budapest.

Semjén András (2013): Költségmegosztás a felsőoktatásban. Utak és tévutak. MTA KRTK Közgazdaság-tudományi Intézet, Budapest.

Temesi József (2012, szerk.): Felsőoktatás-finanszírozás. Nemzetközi tendenciák és a hazai helyzet. Aula Kiadó, Budapest.

Veres Pál (2012): A költség-haszon elv értelmezhetősége a hazai felsőoktatás finanszírozásában. Polgári Szemle, Vol. 8, No. 1-2, 100-122.

Veres Pál (2018): A magyar falu múltja és jövője a részt vevő megfigyelő szemével. Polgári Szemle, Vol. 14, No. 4-6, 213-225.

Veres Pál - Golovics József (2012): Az állam felsőoktatási szerepvállalása. Ezredvég, Vol. 22, No. 5, 99-119.

Vossensteyn, Hans (2004): Fiscal Stress: Worldwide Trends in Higher Education Finance. Fournal of Student Financial Aid, Vol. 34, No. 1, 39-55. 